\title{
Medical Educators' conceptions about Generic Competences in Argentina: Contributions for consensus building
}

\author{
Roberta Inés Ladenheim and Cecilia Inés Hernández*
}

doi: http://dx.doi.org/10.18543/tjhe-5(2)-2018pp99-132

Received: 26.04 .2018

Accepted: 18.05 .2018

\begin{abstract}
Healthcare professionals' education is evolving to meet people's needs towards a more comprehensive, collaborative and interdisciplinary training. In medical education in Argentina, in the context of international discussions around competence-based education (CBE), competence frameworks are being developed for undergraduate and postgraduate education, constituting agreed criteria that lead to the design of training programs and work as key tools to ensure educational quality. The Tuning Project and other international frameworks account for this process towards a common definition of standards beyond geographic and disciplinary boundaries. Generic competences (GCs) have acquired increased relevance in CBE discussions, whereas in medical education they involve key skills for patient safety - yet clarity in their implementation still has to be accomplished. In competence-based medical education (CBME), some changes are being hindered by the absence of a common language as well as diverging ideologies and theories. The purpose of this work was to explore conceptions and the terms used when referring to GCs by people in charge of educational planning and design of Human Resources (HR) training policies in Argentina. A qualitative
\end{abstract}

* Roberta Inés Ladenheim (rladenheim@iuc.edu.ar), MD, is the Director of the Medicine Program and Coordinator of the Specialisation Program in Internal Medicine at the Instituto Universitario CEMIC, Buenos Aires, Argentina.

Cecilia Inés Hernández (cineshernandez@gmail.com) is Teaching Coordinator at the Provincial Coordination of Teaching \& Research at the Health \& Environment Ministry of the Province of Santa Cruz, Argentina.

More information about the authors is available at the end of this article (after the bibliography list).

Acknowledgements: This work was partially carried out at Deusto International Tuning Academy (DITA) at the University of Deusto, Bilbao, Spain, and was financially supported by DITA Short-Term Visit Scholarship (http://tuningacademy.org/short-term-visits-call/). The author would like to thank all participants for the express commitment towards a quality education that defies its own conceptions. 
exploratory study was conducted based on semi-structured interviews to key informants from different levels and fields in medical education. Interviews were conducted by one interviewer and analysed by two independent researchers. Results showed that medical educational planners have different conceptions regarding GCs and fail to share a common language to enunciate them. They acknowledge their relevance for patient safety and agree with the notion that, at this time of educational transformation, it would be useful to enunciate them separately from specific competences, although they realise that this involves potential risks in curricular design. From all terms used in this regard, "generic competence" was identified as a contradiction in itself. Consensus on denomination, meaning and visibility in curricula is mandatory.

Keywords: Competence-based education; competence frameworks, Tuning Project; generic competences; discipline-specific competences; conceptions; human resources in healthcare.

\section{Context, challenges, discussions and possible answers}

\section{I.1. Training healthcare human resources (HR): An overview}

The field of healthcare HR in Argentina is a "constantly evolving intersectoral structure with changing dynamics, and with actors and institutions whose interests are sometimes supplementary and other times contradictory" [our translation].

Argentina is a federal country, in which neither the health nor the education systems are delegated to the State. Therefore, provinces are autonomous for managing health and education. ${ }^{2}$

This structure results in the fragmentation of many processes. In particular, HR training entails complex coordination among several actors, such as the healthcare system, the education system and the field of future labour insertion - each with its own logics, not always integrated consistently. ${ }^{3}$ Against this backdrop of fragmentation, many technician, undergraduate and postgraduate training programs are offered by both public and private technical education institutions and universities.

${ }^{1}$ María Isabel Duré and María del Carmen Cadile, comps., La gestión de recursos humanos en salud - Una estrategia de consensos 2008-2015 (Argentina: Ministerio de Salud de la Nación, 2015), 27.

${ }^{2}$ Hugo E. Arce, "Organización y financiamiento del sistema de salud en la Argentina," Medicina 72, no. 5 (2012): 414-418, http://www.scielo.org.ar/pdf/medba/v72n5/v72n5a11.pdf.

${ }^{3}$ Duré and Cadile, comps., La gestión de Recursos Humanos. 
In the specific case of postgraduate medical education, specialisation training can be accessed in different ways: in educational institutions university postgraduate programs - or in-service training - medical residencies.

Even though the curriculum design of undergraduate programs aims to provide key competences during the training period, some of these competences are not acquired at this stage but are sometimes developed during postgraduate training. To some extent, this shows an education continuum between both periods. ${ }^{4}$ This also becomes particularly relevant given that, unlike inother countries, in Argentina a medical degree authorises professional practice, that is to say, having a specialty is not a precondition for clinical practice.

The State, by virtue of its social accountability as to education and practice regulation, ${ }^{5}$ exercises its stewardship in different ways: “...as educator, employer, auditor of professional practice, and regulator of each of these processes and how all of this structures the field, both when the State is responsible for these activities as well as when it delegates them to other actors" " [our translation].

One way of exercising regulation is through accreditation at the different education levels - undergraduate and postgraduate. Accreditation systems define professional profiles, standards and competences, and are a State policy vis-á-vis HR training. The system consolidation depends mostly on the intersectoral actors at stake, their interests and decision-making power.

\section{I.2. Challenges for current medical education}

Over a century ago, Abraham Flexner presented a report stating what medical education should be like. In his analysis, Flexner stressed the need to strengthen the learning of basic sciences as part of medical training. This had a powerful effect, resulting, at that time, in the proliferation of medical schools whose practice was based in teaching the basic sciences upon which the clinical sciences would develop later on. ${ }^{7}$ Flexner's report became a

${ }^{4}$ Olle Ten Cate, "What is a 21 st century doctor? Rethinking the significance of medical degree," Acad Med. 89, no. 7 (2014): 966-9, doi: 10.1097/ACM.0000000000000280.

${ }^{5}$ Duré and Cadile, comps., La gestión de Recursos Humanos.

${ }^{6}$ Ibid., 31.

7 Carlos A. Brailovsky and Ángel M. Centeno, "Algunas Tendencias Actuales en Educación Médica,” REDU.Revista de Docencia Universitaria 10 (2012): 23-33, doi: 10.4995/ redu.2012.6091. 
turning point in this matter. From that moment on, there have been several proposals, none of which, however, with the same paradigmatic impact.

In 1984 the General Professional Education of the Physician (GPEP) report was published in the United States. This report, among other aspects, underscored the need to introduce content drawn from the behavioural sciences and the social sciences in medical school curricula. ${ }^{8}$ In the $1990 \mathrm{~s}$, a redefinition of medical education was introduced, not so much associated with structures and processes but more relying on outcomes, i.e. the competences a physician should have. ${ }^{9}$

Based on the same approach, other projects were introduced, including the

...Medical School Objectives Project (MSOP) in the United States, the CanMeds project in Canada, the Tomorrow's Doctors project in the United Kingdom and the Physician of the Future (Médico del Futuro) of the Medical Education Foundation (Fundación Educación Médica) in Spain ${ }^{10}$ [our translation].

The Tuning Project was developed in Europe and then in Latin America and other regions of the world. It brought together experts from different disciplines, such as medicine. This project was created with a vision based on networks, learning communities, interprofessional solidarity and respect for the context-specific characteristics of professional practice. In Latin America, specifically in the field of medicine, university representatives worked in the development of a Latin American meta-profile and common competences for physicians. ${ }^{11}$

In 2007, the Project stated that the degree in medicine is still highly disciplinary. ${ }^{12}$ The same observations for Latin America were also made for the rest of the world, when a new study showed that most curricula were still based on a paradigm of fragmentation. ${ }^{13}$

${ }^{8}$ Association of American Medical Colleges, "Physicians for the Twenty-First Century. The GPEP Report: Report of the Panel on the General Professional Education of the Physician and College Preparation for Medicine," J Med Educ. 59, no. 11 (1984): 1-208.

9 Robert Englander et al., "Toward a shared language for competency-based medical education,” Medical Teacher 39, no. 6 (2017): 582-587, doi: 10.1080/0142159X.2017.1315066.

${ }_{10}$ Brailovsky and Centeno, "Algunas Tendencias," 26.

${ }^{11}$ Christel H. Altermatt, "El proyecto Tuning latinoamericano: la experiencia del área de Medicina," Rev Hosp Clin Univ Chile 25 (2013): 19-31.

12 Pablo Beneitone, Reflections on and outlook for higher education in Latin America. Final report-Tuning Latin America Project, 2004-2007 (Bilbao: Universidad de Deusto, 2007).

13 Julio Frenk et al., "Health professionals for a new century: transforming education to strengthen health systems in an interdependent world," The Lancet 376, no. 9756 (2010): 19231958, doi: 10.1016/S0140-6736(10)61854-5. 
Within the context of discussions over educational innovation, in 2010 - a hundred years after its original report - the Carneggie Foundation published the "Educating Physicians" report. The report made four recommendations for the reform:

1) standardizing learning outcomes and individualizing the learning process; (2) promoting multiple forms of integration; (3) incorporating habits of inquiry and improvement; and (4) focusing on the progressive formation of the physician's professional identity.$^{14}$

Thus, the report highlighted that healthcare professionals' education was not up to the challenges posed by society, and that it still relied on a static and fragmented curriculum. It also noted the "tribalism of the professionals" and the tendency to act in isolation from each other - it could also be said that in isolation from social demands.

This is another turning point for medical education. From an optimistic perspective, medical education faces the possibility to effect changes as long as it improves collaboration among professionals in healthcare teams and understands unequivocally that maintaining the medical hegemony would lead down the wrong path. ${ }^{15}$

Along with the changes in society, what is expected and needed from healthcare professionals has also changed. In this respect, physicians in particular are required to adopt a holistic and patient-centred view. This has motivated the inclusion of generic competences in curriculum design proposals. ${ }^{16}$ Apart from developing individual competences, physicians must be able to contribute to the development of team competences, the so-called collective competences. ${ }^{17}$ Therefore, 21 st century physicians ${ }^{18}$ are called to redefine their role within the team, since responding to the care needs of the society requires interdisciplinary work and collaboration among professionals.

${ }^{14}$ David M. Irby, Molly Cooke, and Bridget C. O'Brien, "Calls for reform of medical education by the Carnegie Foundation for the Advancement of Teaching: 1910 and 2010," Acad Med. 85, no. 2 (February 2010): 220, doi: 10.1097/ACM.0b013e3181c88449.

15 Alan Bleakley, John Bligh, and Julie Browne, Medical Education for the Future. Identity, Power and Location (Países Bajos: Springer Netherlands, 2011), doi: 10.1007/97890-481-9692-0.

${ }^{16}$ Karsten A. van Loon et al., "The role of Generic Competences in the entrustment of professional activities: A nationwide competency-based curriculum assessed," J Grad. Med. Educ. 8, no. 4 (October 2016): 546-552, doi: 10.4300/JGME-D-15-00321.1.

${ }^{17}$ Eric S. Holmboe et al., "A call to action: The controversy of and rationale for competency-based medical education," Medical Teacher 39, no. 6 (2017): 574-581, doi: 10.1080/0142159X.2017.1315067.

18 Ten Cate, "What is a 21 st century doctor?" 
Medical curricula must be adjusted to encompass these challenges, otherwise they will step further away from the path proposed by the educational reform; they will continue "circling on the medical education carousel." ${ }^{19}$ In connection to this, Stark and Lattuca ${ }^{20}$ recognise three influences operating on the curriculum reform: external influences, such as the society, government, students and accreditation system; internal influences, including teachers' and planners' conceptions; and institutional influences, like universities, hospitals and organisations. These influences must be considered in order to understand the complexity of the whole process.

\section{I.3. Discussions of healthcare professionals' education within the curriculum change process}

Within this context of change, the literature evidences the discussions held so far, which attest to the tensions in the field. Some tensions have more to do with implementation difficulties in practice and others are more theoretical, conceptual and ideological - different conceptions of the profession, its practice and education. As CBME expands, the most relevant discussions include:

- Observable-Measurable-Assessable / Non-observable: In line with the assessment and psychometric paradigm, CBE discourse requires definitions in observable and measurable terms; criticism has pointed out that not every important matter is measurable. CBE is blind to unmeasurable attributes, possibly important ones, for example some relevant qualities in medical education such as humanism, professionalism, altruism and empathy. ${ }^{21}$

- Conceptions of Competence: There are disagreements regarding what a competence is. This lack of a common language which expresses a univocal meaning generates interference in the implementation of CBME. ${ }^{22}$

${ }^{19}$ Cynthia R. Whitehead, Brian D. Hodges, and Zubin Austin, "Captive on a carousel: discourses of 'new' in medical education," Adv Health Sci Educ Theory Pract. 18, no. 4 (October 2013): 766, doi: 10.1007/s10459-012-9414-8.

${ }^{20}$ Lisa R. Lattuca and Joan S. Stark, Shaping the college curriculum: Academic plans in context (United States: Jossey-Bass Inc., 2009).

${ }^{21}$ Martin Talbot, "Monkey see, monkey do: a critique of the competency model in graduate medical education," Med Educ. 38, no. 6 (June 2004): 587-92, doi: 10.1046/ j.1365-2923.2004.01794.x.

${ }^{22}$ Nicolas Fernandez et al., "Varying conceptions of competence: an analysis of how health sciences educators define competence," Medical Education 46 (2012): 357-365, doi: 10.1111/j.1365-2923.2011.04183.x. 


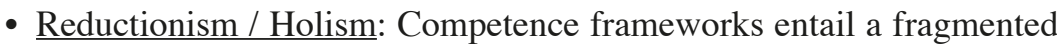
approach to professional practice and, therefore, a distorted truth, with limitations in describing complex human behaviour. ${ }^{23}$ However, explicitly breaking competence down into meaningful components sometimes helps assessment and feedback. Instead of the dichotomy between "holism/reductionism", it may be possible to address practice fragmented or as a whole depending on the situation, knowing that both decisions have potential consequences. ${ }^{24}$

- Individual / Collective Competences: There is the need of rethinking medical competences in a collective discourse, arguing that individual competences are not enough to secure team success and patient safety. ${ }^{25}$

- GCs in Healthcare Professionals' Education: The advent of CBME also resulted in the incorporation, among the learning objectives, of aspects that reach beyond medical expertise, such as communication, collaboration, management skills, and ethics. Despite the need of these GCs, their relevance is not always recognised and their implementation is challenging. ${ }^{26}$ Furthermore, the literature mentions them with different terms, and there is no consensus as to how to include them in the curricula. The above interference related to the term competence is still more marked when it comes to generic competences.

\section{I.4. Reference framework emergence in the context of current discussions: Possible answers, approaches and strategies}

In the context of ongoing discussions on CBME and given the need for providing answers, different alternative training approaches have emerged. In seeking models which allow for competence operationalization, with a comprehensive approach that reveals consensus building, the creation of

${ }^{23}$ Thomas S. Huddle and Gustavo R. Heudebert, "Viewpoint: Taking Apart the Art: The Risk of Anatomizing Clinical Competence," Acad Med. 82 (2007): 536-541.

${ }^{24}$ Eric S. Holmboe, Jonathan Sherbino, Robert Englander, Linda Snell, Jason R. Frank, and on behalf of the ICBME Collaborators. "A call to action: The controversy of and rationale for competency-based medical education," Medical Teacher 39, no. 6 (2017): 574-581, doi: 10.1080/0142159X.2017.1315067.

${ }^{25}$ Brian D. Hodges and Lorelei Lingard L., The Question of Competence: Reconsidering Medical Education in the Twenty-First Century (New York: Cornell University Press, 2012).

${ }^{26}$ Nadine van der Lee, Joanne P. I. Fokkema, and Fedde Scheele, "Generic competencies in postgraduate medical training: their importance illustrated by a doctor's narrative on competency-based practice," Zdrav Var 51 (2012): 280-284, doi: 10.2478/v10152-012-0031-y. 
reference frameworks (RF) shows a clear development within the field of medical education.

RFs are organisers that group ideas or domains, and reflect the educational objectives which trainees are to attain. ${ }^{27}$ These "assumptions" are organised by using a shared language and are a model that standardises what should be done. ${ }^{28}$ They are management tools for those responsible for training.

In Argentina, “...[RFs] are a key tool for harmonising and improving the (postgraduate) training system of the healthcare team at the national level, since they set the basic parameters training programs must take into account." ${ }^{29}$ Reference framework development has been proposed so as to provide quality education, which leads to better care. ${ }^{30}$

The way RFs are designed - drafted - has an impact on their interpretation and on curriculum design. They help to cascade down complex concepts, such as "clinical competence," to planning and assessment stages. There are different types of frameworks. Depending on what aspect they focus on, they may be synthetic - competences - analytic - daily activity - or developmental - progressive development of competences. ${ }^{31}$

In an effort to bring complex frameworks closer to practice, two concepts have been introduced in medicine, both highly widespread nowadays:

27 Alberto E. Alves de Lima and Juan P. Costabel, "Marcos de Referencia para la evaluación del desempeño profesional en el ámbito de trabajo," Rev Fed Arg Cardiol 44, no. 2 (2015): 118-123.

${ }^{28}$ Louis Pangaro and Olle Ten Cate, "Frameworks for learner assessment in medicine: AMEE Guide No 78," Med Teach 35, no. 6 (June 2013): 1197-210, doi: 10.3109/0142159X.2013.788789.

${ }_{29}$ Ministerio de Salud de la Nación, Guía para la elaboración de Marcos de Referencia (Argentina: Ministerio de Salud de la Nación, 2013). This guide for the elaboration of reference frameworks was designed by the National Directorate for Human Resources and Occupational Safety and Health (Dirección Nacional de Capital Humano y Salud Ocupacional) of the Argentine Ministry of Health, together with representatives from scientific and academic societies, experts in different areas, members of specialty-related programs and professionals with extensive experience. The objective of this guide was to agree on a document at the national level which contained the basic criteria and the methodology for the design of reference frameworks for the different specialties. This guide provides the basic guidelines for the design of specific reference frameworks and the different specialties.

${ }^{30}$ Royal College of Physicians and Surgeons of Canada, "Better standards, better physicians, better care,” accessed April 2018, http://www.royalcollege.ca/rcsite/canmeds/ canmeds-framework-e. In the 1990s, the Royal College of Physicians and Surgeons of Canada developed the CanMEDS model with a view to defining the competences needed for effectively meeting people's heathcare needs. The goal of CanMEDS is to improve patient care. This framework has been adopted and adapted in many countries. Since it was created, CanMEDS has undergone several revisions, which are key to its improvement. The framework has the motto "Better standards, better physicians, better care."

31 Alves de Lima and Costabel, "Marcos de Referencia." 
Entrustable Professional Activities (EPAs) ${ }^{32}$ and Milestones. Milestones "define a developmental trajectory for individual competencies. EPAs are observable and measureable units of work that can be mapped to competencies and milestones critical to performing them safely and effectively." 33 Both terms are used in diverse international curriculum planning contexts as tools to set clear learning objectives and facilitate the assessment of their scope. These concepts could be established as a facilitating language that brings transparency to the different local interpretations and fosters consensus-based work and collaboration. ${ }^{34}$

In 2013, a guide for RF development ${ }^{35}$ was designed in Argentina. One of its objectives was to contribute to the implementation of collaboration processes and exchanges among institutions and/or specialties - among and inside provinces. In this line of work and with an international perspective, the Tuning Project has aimed to create an interdisciplinary reference framework, seeking to enhance understanding/communication through a language shared by the actors involved and achieving a consensus on common international standards. ${ }^{36}$

32 Olle Ten Cate, "Entrustability of professional activities and competency-based training," Med Educ. 39, no. 12 (2005): 1176-1177, doi: 10.1111/j.1365-2929.2005.02341.x. EPAs (Entrustable Professional Activities) were introduced by Olle Ten Cate in 2005, in the Netherlands. EPAs describe specialist physicians' routine activities for safe and effective care provision. They describe observable behaviour units. This has turned EPAs into a highly relevant training tool. EPAs are very much developed in the United States, Canada, the Netherlands and the United Kingdom. In Argentina, the Hospital Italiano de Buenos Aires has started their implementation in its medicine program. In addition to EPAs, the ACGME has developed Milestones.

${ }^{33}$ Carol Carraccio et al., "Building a Framework of Entrustable Professional Activities, Supported by Competencies and Milestones, to Bridge the Educational Continuum," Acad Med. 92, no. 3 (March 2017): 324, doi: 10.1097/ACM.0000000000001141.

${ }^{34}$ Olle Ten Cate, "Competency-Based Education, Entrustable Professional Activities, and the Power of Language," J Grad Med Educ. 5, no. 1 (March 2013): 6-7.

${ }^{35}$ Ministerio de Salud, Guía para la elaboración. Based on the guide for the elaboration of framework documents in Argentina, other reference frameworks have been developed for different medical specialties. The Argentine Ministry of Health, through its National Directorate for Human Resources and Occupational Safety and Health (DNCHySO), leads these processes by organising work committees made up of representatives from the Ministry of Health, members of scientific and academic societies and jurisdiction representatives. To the day, there are eleven reference frameworks for different specialties approved by the Federal Health Council (COFESA) and six are undergoing a consolidation process (http://www.msal.gob.ar/ residencias/index.php/la-acreditacion/documentos-marco-de-referencia-de-especialidades). Reference frameworks determine the minimum standards for professional profiles, the basic methodological/structural criteria and the training trajectory for each specialty.

${ }^{36}$ Robert Wagenaar, "Competences and learning outcomes: a panacea for understanding the (new) role of Higher Education?" Tuning Journal for Higher Education 1, no. 2 (2014): 273-302, doi: 10.18543/tjhe-1(2)-2014pp279-302. 


\section{The Problem: "Tribalism" 37 of educational practices, professions and language}

The growing complexity of healthcare practices imposes healthcare professionals' education the challenge of training professionals with competences that match this complexity, adopting a holistic and comprehensive approach. However, more often than not training approaches are still characterised by fragmentation. This, in turn, is reproduced in the care settings where students are trained and where they will exercise professional practice. ${ }^{38}$

Efforts towards more comprehensive training approaches still evidence some flaws and remain more in the declarative than in the action domain. They end up being more reproductive of dated practices than actually productive and innovative, thus giving the feeling of being at a standstill..$^{39}$ Both at universities as well as in the care settings where in-service training is provided, training practices take place in environments characterised by fragmentation, isolation of professions, lack of teamwork and interprofessional collaboration. ${ }^{40}$

Strong tensions coexist among training institutions and the need for profiles required by the health system. Given a deeply rooted training model, with a discipline-based approach which does not favour collaborative work with other professions, a hospital-centred view of healthcare that restricts the field of intervention and a heavy reliance on technology ${ }^{41}$ changing training structures and curricula is not enough - even if there is a trend towards abandoning discipline-based curricula. ${ }^{42}$ The result is a change in form but not in substance, since students are trained in the intersection of both systems, where both, still fragmented, logics struggle.

The Pan American Health Organization (PAHO) "Health Agenda for the Americas" (PAHO/WHO,Health Agenda for the Americas 2008-2017, Washington, DC: PAHO, 2007) drawn up and approved by all Ministers of Health of the Americas, proposed to

start a joint effort with the countries in the Region to make it possible to redefine physician training in the Region. The purpose is to pursue

37 Jo Atkins, "Tribalism, Loss and Grief: Issues for Multiprofessional Education," Journal of Interprofessional Care 12, no. 3 (1998): 303-307, doi: 10.3109/13561829809014121.

${ }^{38}$ Frenk, et al., "Health professionals."

39 Whitehead et al., "Captive on a carousel."

${ }^{40}$ Frenk, et al., "Health professionals."

${ }^{41}$ Duré and Cadile, comps., La gestión de Recursos Humanos.

${ }^{42}$ Pan American Health Organization, Formación en Medicina orientada hacia la atención primaria de la salud - Serie la Renovación de la Atención Primaria de Salud en las Américas. No. 2 (Washington D.C: PAHO, 2008). 
community-based education with a generalist approach, with public healthcare contents and family and community healthcare contents, and, especially, with a primary care approach that enables graduates to develop solid technical and social competences, interdisciplinary thinking and ethical behaviour ${ }^{43}$ [our translation].

It has been stated that health systems must provide "comprehensive, integrated and adequate care along time, placing emphasis on prevention and promotion, securing the users' first contact with the system and taking families and communities as the basis for planning and action"44 [our translation].

On the other hand, the fragmentation between the training and the health systems is evidenced in a variety of ways: overspecialised physicians, whose practices are founded on a biology-centred model, are hospital-centred and lack contextual insight; or physicians with segmented training, few skills for primary care management in terms of prevention and promotion ${ }^{45}$ and little development of GCs. Scientific and technological development has changed the practice landscape and has contributed to the emergence of new tasks and actors, giving rise to super-specialists who "struggle for exclusiveness in certain areas of intervention." 46

The complexity of healthcare social needs demands the organisation of work in teams, with the lack of team work skills - both inter - and intra-healthcare professionals - being considered as one of the strong reasons why serious medical errors are made. In this context, there is a need for competences that go beyond the boundaries of a discipline, to be potentially developed across the board. Here, the ability to participate in work teams and interdisciplinary work is key. ${ }^{47}$

The topic of GCs and their incorporation in the curricula are undergoing a process of constant discussions, which reveal an attempt to reach out to social care needs in order to meet them with a particular professional profile. However, there is a gap between discursive formulation of competences and their learning and implementation in real life contexts. Discourse models the way these competences are understood and also implemented. ${ }^{48}$ The lack of

${ }^{43}$ Pan American Health Organization, Formación en medicina, 2.

44 Ibid., 2.

45 Ibid.

${ }^{46}$ Jurjo Torres Santomé, Globalización e interdisciplinariedad: el curriculum integrado (España: Ediciones Morata, 1994).

${ }^{47}$ Cristina Davini and María Isabel Duré, coords., Guía para la elaboración de. Documentos Marco de Referencia. (Buenos Aires: Mimeo, 2013).

${ }^{48}$ Cynthia R. Whitehead, "Getting off the carousel: De-centring the curriculum in medical education,” Perspect Med Educ. 6, no. 5 (October 2017): 283-285, doi: 10.1007/s40037-017-0373-x. 
a shared language in this respect has been pointed out as a hindrance, since in the field of education there are different terms, definitions and classifications to refer to "soft skills." 49

The situation of neglect ${ }^{50}$ of these competences was addressed in 2016 by the Association for Medical Education in Europe (AMEE), by referring to them as "orphans".

Furthermore, it cannot be overlooked that educational systems are placed in a certain time and context, and are, therefore, immersed in a specific historical process. The same competences, with the same names, may articulate different meanings in each region, since contextual factors have a bearing on these definitions. In Beneitone's words: "On the other hand, there are clearly differences in the expectations and conceptions of generic competences which reflect cultural values and concepts." ${ }^{51}$ The context also encompasses the disciplinary context, which has a particular view of generic competences and makes it difficult to achieve consensus since what is considered important varies across regions and disciplines. ${ }^{52}$

Even though EPAs were an attempt to incorporate generic competences, it was observed that in practice these competences were not actually prioritised. There is a gap between the intent to incorporate them and their implementation in practice..$^{53}$

In Argentina, there are documents which regulate medical education both at the undergraduate and postgraduate levels. Regarding the so-called generic competences, documents refer to different terms, definitions and manners in which the generic and specific aspects of competences are linked. Documents also propose different ways of planning their teaching and assessment and of including them in the process of quality education accreditation; this probably suggesting different conceptions among planners. At the undergraduate level, ${ }^{54}$

49 Maria Cinque, “'Lost in translation'. Soft skills development in European countries," Tuning Journal for Higher Education 3, no. 2 (2016): 389-427, doi: 10.18543/tjhe-3(2)2016pp389-427.

50 Jordi Palés-Argullós and Maria Nolla-Domenjó, "Generic competencies, an unresolved issue in faculties of medicine," FEM 19, no. 5 (2016): 227-228.

51 Pablo Beneitone and Edurne Bartolomé, "Global generic competences with local ownership: a comparative study from the perspective of graduates in four world regions," Tuning Journal For Higher Education 1, no. 2 (2014): 331, doi:10.18543/tjhe-1(2)-2014pp303-334.

${ }^{52}$ Lazarus Nabahodoi, "Developing Generic Competences in Life Sciences: the untold story of the Makerere University College of Health Sciences in Uganda," Tuning Journal For Higher Education 4, no. 2 (2017): 389-406, doi: 10.18543/tjhe-4(2)-2017pp389-406.

${ }^{53}$ Loon van, et al., "Role of Generic Competencies."

${ }^{54}$ Resolution No 1314/07 Ministerio de Educación de la Nación Argentina, Estándares para la acreditación de carreras de Medicina, CONEAU. Resolution $\mathrm{N}^{\circ} 1314 / 07$, approved by 
the accreditation standards in the medical school do not explicitly mention the term "generic competences." Even though they are included, they are not referred to as such. At the postgraduate level, particularly for in-service training - Medical Residencies - a guide for the elaboration of reference frameworks was proposed as part of the leadership role assumed by the State in order to provide the overall guidelines for the design of framework documents in different specialties, with the agreement of the actors involved - scientific societies, universities, ministries. This guide includes general competences, competence areas and, explicitly, "transversal competences." On the one hand, the guide proposes that the specific contents should be selected in accordance with the type of specialty and, on the other hand, it suggests "transversal contents" common to all specialties. Today, these contents are organised in three "blocks of transversal contents," grouped around three pillars: the role of the professional as part of and actor in the system to secure the right to health; the link between the professional and other legal entities which access health institutions; continuing education and research for care improvement. ${ }^{55}$ These pillars tackle central problems for the healthcare system which are common to all specialties. In the different specialty-specific frameworks developed since 2010 to date, the actors involved in framework development have taken into consideration the incorporation of transversal contents diversely, accounting for the progress made in this respect and also for the difficulties in implementing and interpreting them.

The Tuning Project has made significant progress as to the definition of competences, distinguishing between specific and generic competences. In the experience of the Tuning Latin America 2011-2014 ${ }^{56}$ work group in the

the Argentine Ministry of Health, determines the accreditation standards for the medical programs. Available: http://www.coneau.edu.ar/archivos/Res1314.pdf. The resolutions approved by the Argentine Ministry of Health in 2006 and 2007, respectively, are the Ministerial Resolutions 450/06 and 1342/07. Resolution 450/06 determines the creation of the National Accreditation System of Health Team Residencies (Sistema Nacional de Acreditación de Residencias del Equipo de Salud), which establishes basic criteria and system members, as well as the creation of the National Single Registry of Accredited Health Team Residencies (Registro Nacional Único de Residencias del Equipo de Salud Acreditadas) and the Single Registry of Heath Team Residency Assessment Bodies (Registro Único de Entidades Evaluadoras de Residencias del Equipo de Salud). Resolution 1342/07 determined the implementation of the National Accreditation System of Health Team Residencies, created by Resolution 1342/07.

${ }^{55}$ Ministerio de Salud de la Nación, Resolution 1342/2007 - Residencias del equipo de salud/Sistema nacional de acreditación de residencias, Official Gazette 26-oct-2007 no. 31268.

${ }^{56}$ Christel H. Altermatt, ed., Educación Superior en América Latina: reflexiones y perspectivas en Medicina (Bilbao: Universidad de Deusto, 2013). 
field of medicine, difficulties were observed when trying to materialise this distinction in a reference framework and, even more so, in different practices. When formulating the specific competences of physicians, they made a list containing the specialty-specific competences, some of them markedly illness-oriented, some involving concrete specific disciplinary skills and others of a more generic nature, such as the "ability to participate actively in the health team and the community."

When working on GCs, they decided to treat the generic competence "communication" as both generic and specific, thus revealing the blurred boundaries when it comes to defining it one way or the other. In the context of the Tuning Project, they stated that in practice generic competences seem not to be clearly separated from specific competences as they must always be interpreted in the light of the disciplinary area.

Regulatory frameworks seek to define a common ground, trying to maintain a delicate balance and understanding the need to be explicit and provide definitions so that these can be used for determining the implementation, course and development of training. ${ }^{57}$

Given the fragmentation of the training system, the health system and language, new lines of work have emerged which try not to go further into the same logic, but rather to look for a way of bridging the gap among disciplines by incorporating generic competences in training and by seeking agreements to define a shared language.

However, when it comes to what is termed as "generic competences" there seem to be several interpretations, uses and terms, there being differences in literature, official and public documents. Apparently, but is the same referred to or spoken of? What conceptions do underlie these differences? Planners' conceptions regarding generic and specific aspects might be operating in this situation.

\section{II.1. The Gap between what is thought and what is said: Underlying conceptions and terms}

As Peters et al. state, "[c]onceptions are beliefs or ideas that function as lenses through which people view and interpret the world... These conceptions are important because they act as cognitive filters that may

${ }^{57}$ Martin Mulder, "Conceptions of Professional Competence," in International Handbook of Research in Professional and Practice-based Learning, ed. Stephen Billett, Christian Harteis, and Hans Gruber (Dordrecht: Springer, 2014). 
influence teachers' and workplace supervisors' teaching strategies and students' learning strategies". ${ }^{58}$

From this perspective, a conception is a way of interpreting, understanding and slicing a certain reality, distinguishing what is relevant from what is not, and determining what is included or excluded. Conceptions can materialise in the use of language. They may have theoretical, historical, subjective and contextual components, which render the transition to materialization difficult. In other words, there is a relation between conceptions and terms. This relation is mediated by diverse influences and convenience, and is not devoid of consequences.

One of the functions of language is to articulate and organise thought. According to Gimeno Sacristán, "[c]oncepts, arguments and speeches are tools that reflect the content matter of our thoughts, while the language we use...conditions our pattern of thinking and how we make it objective..." ${ }^{59}$ [our translation]. Therefore, the terms we choose and use to name concepts are not naïve. On the contrary, they act as lenses through which reality is seen in a certain way; as the saying goes "it lies in the eyes of the beholder," that is, "the choice of language used is not arbitrary." ${ }^{60}$ One same term, depending on the user and the context of use, may carry different meanings.

In the area of medical education, CBME implementation has entailed a change in the way problems are defined, interpreted and tackled. This is a type of lens that impacts on education planning. Conceptions have an impact on curriculum planning, since they limit expectations and the contents which are included and excluded, all of this having an effect on practice - teaching and assessment modes.

Planners might act as agents for change - or resistance. Conceptions come into play in various circumstances. Teaching practices are influenced by teaching and learning conceptions, even when these are not made explicit. ${ }^{61}$

${ }^{58}$ Sanne Peters et al., "A Qualitative Exploration of Multiple Perspectives on Transfer of Learning Between Classroom and Clinical Workplace," Teach Learn Med. 30, no. 1 (Jan-Mar 2018): 22, doi: 10.1080/10401334.2017.1339605.

59 José Gimeno Sacristán, "Diez tesis sobre la aparente utilidad de las competencias en educación,” in Educar por competencias, ¿qué hay de nuevo?, comp. José Gimeno Sacristán (Madrid: Morata, 2008), 17.

${ }^{60}$ Ibid.

${ }^{61}$ Johanna Jacobs et al., "Impact of institute and person variables on teachers' conceptions of learning and teaching," Medical Teacher 37, no. 8 (2015): 1-9, doi 10.3109/ 0142159X.2014.970985. 


\section{Research design}

This was a qualitative exploratory study. The objective of this study was to explore medical educational planners' conceptions regarding generic competences in Argentina and the language choices they make when referring to them. Semi-structured interviews were conducted with key informants involved in health science curricular planning in Argentina

Healthcare HR training in Argentina is complex and includes government, university, healthcare and scientific society actors. Considering this complexity, non-probabilistic sampling was carried out. Sampling relied on strategic informants from different sectors and fields who participate in health HR planning/training - public/private, undergraduate/postgraduate, education and health ministries/universities/scientific societies. Based on this criterion, a selection was made of medical education experts with active participation in decision-making at different levels of educational planning. Experts in medical training were included as long as they had knowledge on competences and theories of generic and specific competences, as well as some past involvement in educational planning processes. To be included, these key informants had to meet the following criteria:

- Proven expertise in medical/professional healthcare education - either from training/specialization in the subject or from an acknowledged career in the area.

- Current or past involvement in curriculum planning or policy-making in medical education - ministries: frameworks and policies; universities: authorities and program directors or coordinators.

Focus was placed on obtaining a significant sample, thus enhancing the research. Indeed, this methodology boosted the investigation and was not expected to be representative of all the situations that occur within a given structure. It also helped to explore different conceptions from different professional realities and institutional contexts. However, the sample was not meant to be representative. Sample size was based on data saturation, specifically linked to the main goal in this survey. It was decided to stop conducting the interviews once the information for the selected categories - definitions and terms/generic-specific relationship - became repetitive and no new data could be collected in this respect.

Data were obtained from semi-structured interviews conducted in Spanish by one researcher (RIL) between July and September 2017. Interviewees were first contacted by email/phone and then summoned for either a personal interview or a Skype call. Informed consent for anonymous use of collected data 
was provided. All interviews were recorded with interviewee authorization and then transcribed for analysis. A preliminary interview was designed, and was later adjusted during the process of conducting the interviews. These instrument adjustments were the result of an ongoing review process. The interviews were conducted until it was not possible to collect new information on both the categories of "definition and terms" and "generic-specific relationship." This means that the final sample size was determined by the data saturation criterion.

\section{Interview protocol}

- What do you think Generic Competences are?

- How do you define generic competences?

- There are different terms-transversal, generic, orphan, domain-independent, soft... do you find them all consistent?

- Do you find one more appropriate or accurate than others?

- Do you think they all refer to the same?

- Why do you think there are so many definitions? And terms?

- Which one do you think is more suitable to describe the process?

- How are specific and generic competences different?

- Advantages of separation?

- In which cases do you consider it useful to separate generic and specific features from professional competence?

- Have you witnessed different moments in educational planning regarding generic and specific competences?

- Which stages do you recognize in this process? When does the difference between specific and generic competences emerge?

- At what point and why is this distinction introduced in the teaching of medicine?

- Do you believe generic aspects of competences should be included in professional profiles? In learning outcomes?

- In those curriculums you have participated, how are generic aspects approached?

- Have you chosen to enunciate them apart from specific aspects? Why?

- What planning decisions have to be made regarding integration or separation of generic and specific aspects of competences, namely in curricular planning, subjects, frameworks, activities?

A content pre-analysis was conducted, consisting of an overall reading of the interviews. Then, a category system was developed using an open coding system. Categories were defined based on the theoretical framework and the interviews. The information surveyed in this study was systematised using codification, comparison and synthesis processes, crossing textual units and interpreting them contextually. An independent analysis was conducted by both researchers (RIL-CIH) to minimise interviewer subjectivity. In addition, a document survey was carried out to "augment and support" the data obtained in the interviews, with a view to using different sources for a more 
in-depth study and consistent analysis. The document sources used comprised official and public documents ${ }^{62}$.

The following table presents the selected categories and their operationalisation. Even though the interviews delved into other relevant aspects - relative to contexts, actors, and the health HR training field - the priority was to explore the categories connected to definitions and terms, as well as the generic-specific relationship.

\begin{tabular}{|c|c|c|}
\hline Dimension & Category & Category operationalization \\
\hline \multirow{2}{*}{ Conceptions } & Definition and terms & $\begin{array}{c}\text { Competence definition } \\
\text { Generic competences }\end{array}$ \\
\cline { 2 - 3 } & $\begin{array}{c}\text { Specific-generic } \\
\text { relationship }\end{array}$ & $\begin{array}{c}\text { On their incorporation } \\
\text { On their enunciation }\end{array}$ \\
\hline
\end{tabular}

\section{Results}

A total of twelve interviews were conducted, each lasting 26 to 86 minutes - an average of 56 minutes. Interviewees come from different areas in the educational practice, undergraduate and postgraduate levels, public and private environments and professions.

During the interviews, the interviewees provided data on their involvement in HR training in Argentina, their affiliation, their role in different contexts, and their training on medical or healthcare professional education. As to gender, the sample was made up of 8 female (F) and 4 male (M) subjects. Considering profession, it was mostly made up of 8 physicians and 4 Educational Science professionals. The eight physicians stated that they had training in education. Four interviewees had a bachelor's degree in education. Even though their professional background was related to education in other disciplines, they were connected with healthcare professionals' training.

Both the undergraduate and postgraduate levels of medical education were represented in the sample. Almost all the interviewees in the sample were involved both in undergraduate $(\mathrm{Gr} ; 11)$ as well as in postgraduate medical education (PGr; 10). They played a role at the level of program direction or coordination and participated in curricular design not only in the medicine degree but also in specialisation programs and medical residencies.

${ }^{62}$ Antonio Alaminos Chica and Juan Luis Castejón Cost, Elaboración, análisis e interpretación de encuestas, cuestionarios y escalas de opinión (Alicante: Universidad de Alicante, 2006). 
Furthermore, as regards management types, interviewees were distributed in two categories: public $(\mathrm{Pu} ; 5) /$ private $(\mathrm{Pr} ; 7)$ management. Seven of them were involved in training at national or provincial ministry levels (Health and Education), either as members/officials or as participants in the processes setting standards and framework documents for regulating training. Six interviewees worked in the Health system $(\mathrm{H})$ carrying out care, management, and/or research tasks. Seven interviewees were involved in ministerial/ reference framework-building.

As explained before, due to the characteristics of the Argentine Health System, actors' - planners' - labour insertion, affiliation, and performance entail simultaneously different contexts, management types, and different roles in the healthcare and educational systems. Interviewees' different roles in the healthcare and educational systems are shown in Table 1 below.

Table I

Characteristics of Interviewees (as reported by them)

\begin{tabular}{|l|c|}
\hline Gender (F/M) & $\begin{array}{c}\text { Female: } 8 \\
\text { Male: } 4\end{array}$ \\
\hline Profession & $\begin{array}{c}\text { Physician: } 8 \\
\text { Educational Science: } 4\end{array}$ \\
\hline Undergraduate medical education involvement (Gr) & 11 \\
\hline Postgraduate medical involvement (PGr) & 10 \\
\hline $\begin{array}{l}\text { Ministerial/reference framework-building involvement } \\
\text { (Mi) }\end{array}$ & 7 \\
\hline Public/private management (Pu)/(Pr) & $\begin{array}{c}\text { Public: } 5 \\
\text { Private: } 7\end{array}$ \\
\hline Health system participation (H) & 6 \\
\hline
\end{tabular}

For the purposes of this article and based on our study objectives, the most relevant categories of analysis were selected. These categories are presented in the matrix format below, including a selection of the most representative quotations. Texts have been translated verbatim from Spanish.

It is worth noting that the interviews provided data concerning the factors and tensions as to the incorporation of generic competences in healthcare professionals' training. While these data were not connected to the main study objectives, they contribute to ongoing discussions and show the implications of this research in the context of healthcare HR. These data are included at the end of the matrix. 


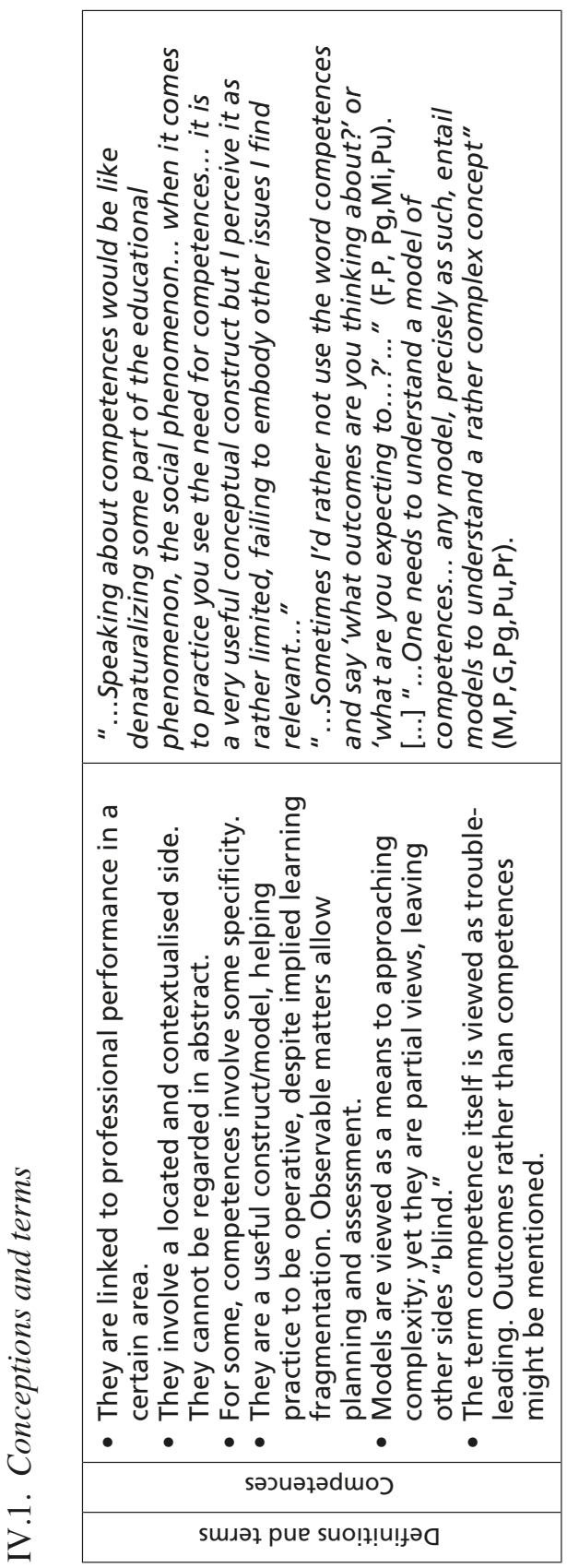

Tuning Journal for Higher Education 


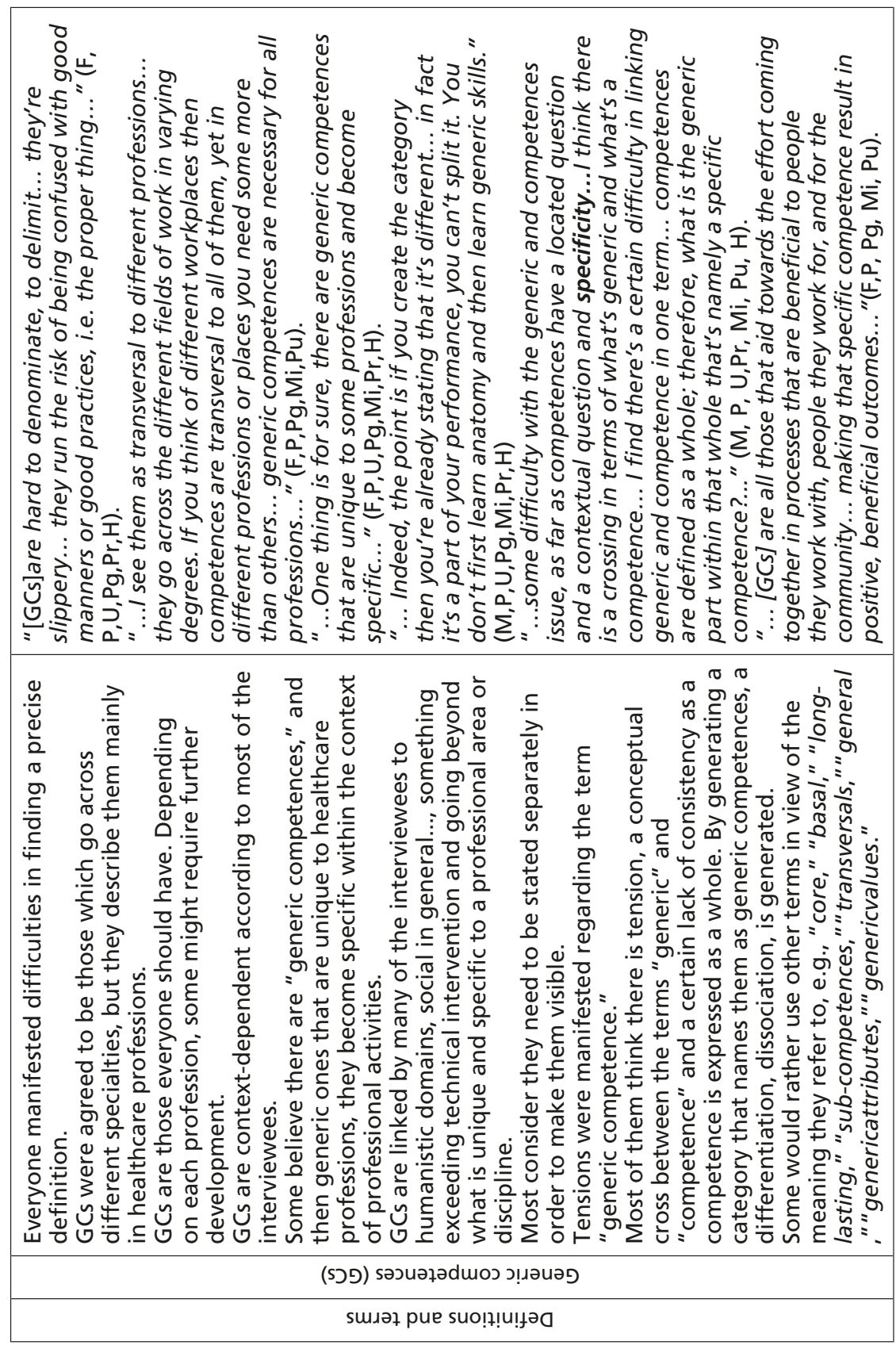

Tuning Journal for Higher Education 


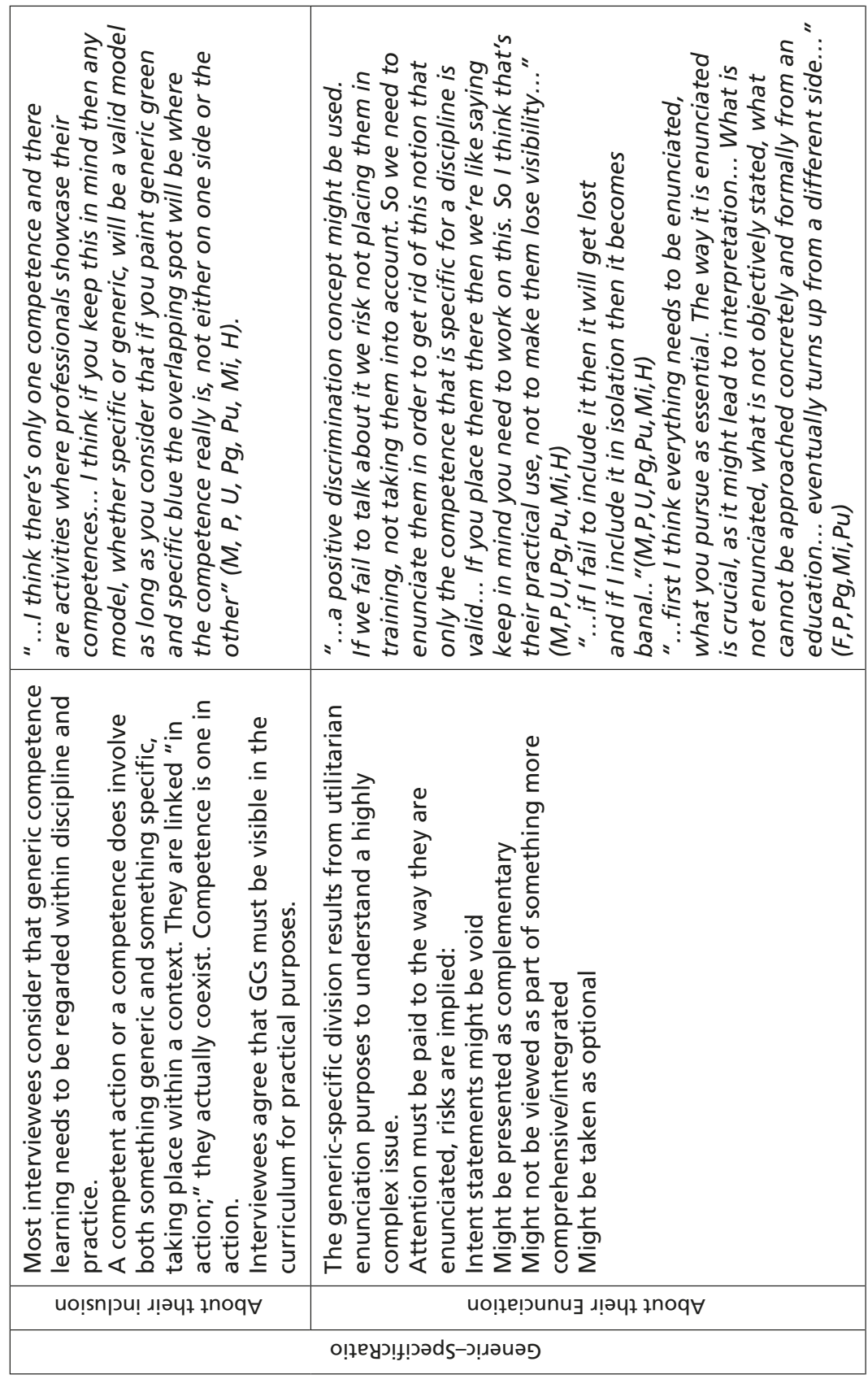




\section{IV .2. Field factors operating on the reform process}

It was pointed out that both the healthcare and the educational systems are to be involved in the process of changing different logics and different predispositions towards it. Regarding this topic some stated that:

...teaching teams which, in our case, respond to two logics, namely, those of the healthcare system and the educational system - the former not always prone to change $(\mathrm{F}, \mathrm{E}, \mathrm{U}, \mathrm{Pu})$.

...Once you finish [the medical program] the discipline matrix is so strong, so strong that deconstructing it or being able to work with generic competences would require double effort.. I think it's a major challenge. I believe it's being increasingly considered and approached... (F,P,Pg,Mi, $\mathrm{Pu})$.

The degree of medicine continues to support a deeply-rooted disciplinary approach which acts as a hindrance to change. GCs have only been included recently in health science curricular planning as a result of an approach opening towards other disciplines and their inputs. Some refer to this issue by saying:

...Actually this has evolved with the growth of health science careers, research in medical education, with increasing acceptance of contributions from other disciplines in the health science career (F,E,U,Pg,Pr).

...I believe one of the main change drivers is thinking you can improve what you're doing...there are high stakes favouring their feuds, let's say, so why would they change when they're OK like that. No one is willing to risk their power, so it's hard to budge in such a structure. Change is unlikely...(M,P,U,Pg,Mi,Pr,H).

I believe these are hard roads to tread since power stands in the middle. Änd this also needs to be said, each one exerts power over their own piece and, therefore, any process... any cross-cutting process would involve yielding power. When you cross-cut you yield power. You're surrendering a piece of your lot. Interdiscipline means yielding power. You're surrendering to someone else something you owned... it's a loss of power both at an individual and an institutional level... (F,P,Pg,Mi,Pu).

\section{Discussion}

The main objective of this study was to identify educational planners' different conceptions of generic competences, as well as to look into the role of the language and terms used to refer to them. These objectives were 
established based on the assumption that the conceptions of the actors involved influence curricular planning decisions. It was also considered that these conceptions are made explicit in language and that this, in turn, affects curriculum implementation. In other words, conceptions and language are related and both have a conditioning effect on practice.

The results show that medical education planners in Argentina have varying conceptions as to what generic competences are, and do not share a common language in this respect.

In general, interviewees connected competences to a certain field of knowledge and professional practice. They all considered that competences are situation- and context-bound, and, therefore, cannot be isolated from their environment or be thought of in the abstract.$^{63}$ Interviewees conceived of competences as a construct, a useful model which makes it possible to determine expected outcomes and, in this way, "operationalise" practices. They agreed with the literature ${ }^{64}$ that competences must be defined by observable behaviour, so that they are measurable and subject to assessment. Indeed, interviewees considered that observable phenomena enable planning and performance assessment. Most of them expressed the need for a competence-based approach in practice, even if this entails a fragmentation/ denaturalisation of the learning process.

In relation to this, ${ }^{65}$ the benefits of making explicit the significant components of competences are acknowledged, since this is extremely useful for assessment and feedback. However, the act of "breaking down competences in order to see them more clearly" neglects fundamental aspects of human behaviour. In this respect, it was not clear among interviewees which important aspects are not taken into account, even though they stated that there is a limit to this theoretical framework. Some believed, in agreement with Lorelei Lingard' concepts ${ }^{66}$ that models or taxonomies facilitate addressing complex issues, even if they always provide a partial view of a phenomenon and "blind" its other side.

Regarding the term "competence," interviewees stated that the term itself presents difficulties. They suggested that it would be possible to speak of

${ }^{63}$ Carlos A. Brailovsky, "Educación médica, evaluación de las competencias," in Aportes para un cambio curricular en Argentina 2001, ed. PAHO/WHO (Buenos Aires: Facultad de Medicina, 2001), 103-120.

64 Talbot, "Monkey see, monkey do."

${ }^{65}$ Holmboe et al., "A call to action."

${ }^{66}$ Lorelei Lingard, "What we see and don't see when we look at 'competence': notes on a god term," Adv Health Sci Educ Theory Pract. 14, no. 5 (November 2009): 625-8, doi: 10.1007/s10459-009-9206-y. 
outcomes without referring to competences. The literature describes similar difficulties with the term "competences." 67

\section{V.1. How generic are generic competences?}

Interviewees expressed their difficulty in providing a precise definition of what generic competences are. However, they conceived of generic competences as those which are common to different professions. In connection to this, several authors have conducted research on generic competences at the international level. The Tuning Project considers that generic competences are those which can be present in different professions. ${ }^{68}$ However, some of the interviewees thought generic competences were related to healthcare professionals instead of all professions. This shows a disciplinary bias and reveals a tension resulting from blurring disciplinary boundaries. ${ }^{69}$

Everyone should have generic competences. However, depending on the profession some competences may require more development or specificity than others. ${ }^{70}$ Several interviewees indicated that there are "generic" competences and generic competences specific to medicine. This means that a generic concept turns into a specific one in this context. This is in line with what the Tuning Project has pointed out, in terms of the difficulty of setting a clear boundary between what is generic and what is specific. ${ }^{71}$

Most interviewees linked generic competences with "humanities-related issues," social matters in general, exceeding technical intervention and the specific concerns of a discipline or profession. Likewise, without much precision regarding the concept, they thought of generic competences as opposed to hard competences and similar to soft ones, like in the literature. ${ }^{72}$

In this context, the guide for the elaboration of framework documents by the Argentine Ministry of Health (MSAL) refers to these competences as those which "bring richness, value and quality to practice"73 [our translation].

${ }^{67}$ Fernandez et al., "Varying conceptions of competence."

${ }^{68}$ Beneitone et al., eds., Reflections on and Outlook.

69 Torres Santomé, Globalización e interdisciplinariedad.

70 Altermatt, "El proyecto Tuning latinoamericano."

${ }^{71}$ Christel H. Altermatt, ed., Educación Superior en América Latina: reflexiones y perspectivas en Medicina (Bilbao: Universidad de Deusto, 2013).

${ }_{72}$ Marcos F. Barrera Morales, Modelos epistémicos en Educación y en Investigación (Caracas: Sypal, 2007).

73 Ministerio de Salud, Guía para la elaboración, 10. 
There are several works arguing that "when problems arise in practice, these competences are involved." ${ }^{74}$

Most interviewees stated that generic competences are determined by the context and depend on it. Studies support this belief, ${ }^{75}$ showing that different actors, disciplines and contexts prioritise different generic competences.

To refer to generic competences publications use different terms ${ }^{76}$ sometimes interchangeably and not necessarily alluding to the same concept or using precise definitions. Several terms, which are used in the bibliography, were coined in journals. Other terms, like "core," "basal," "long-lasting," "sub-competences," "transversals," "general," "generic attributes," and "generic values," were also introduced. Interviewees showed different preferences for one or the other, depending on the meaning they convey. The lack of consistency in the use of terms may be the result of wrong interpretations, since some of these words are used to describe other concepts in the field of training and are not equivalent to generic competences.

As Gimeno Sacristán notes, "language is not naïve" [our translation]. The choice of a term is always driven by certain convenience ${ }^{78}$ and arbitrariness. Apart from this structural condition of language, the term "generic competence" seems to carry/entail itself a problem, since most of the interviewees observed a conceptual overlapping between the terms "competence" and "generic," producing a cognitive dissonance. ${ }^{79}$ There seems to be a contradiction, because "competence" alludes to certain context-bound specificity and "generic" indicates the possibility of repetition/ reproduction in different contexts.

The similarity between the terms "generic" and "general" may cause a problem. The 2013 MSAL guide for the elaboration of framework documents mentions the general competence and defines it as a

complex and integrated set of functions, capacities and abilities that professionals in the area can employ in various real-life work situations in

74 Palés-Argullós and Nolla-Domenjó, "Generic competencies."

75 Beneitone and Bartolomé, "Global generic competences."

${ }^{76}$ Cinque, "Lost in translation." .

77 Gimeno Sacristán, "Diez tesis," 17.

${ }^{78}$ Michel Foucault, "La prosa del mundo," in Las palabras y las cosas. Una Arqueología de las ciencias humanas (París: Éditions Gallimard, 1966), 26-52.

${ }^{79}$ Leon Festinger, A theory of cognitive dissonance (Standford California: Stanford University Press, 1957). 
order to solve the problems these situations pose, according to professional standards and social accountability criteria ${ }^{80}$ [our translation].

In other words, the term "general competence" is used with a different meaning from "generic competence."

\section{V.2. Separating 'generic' from 'specific'?}

Some interviewees expressed their reluctance to place generic competences separated from other competences, suggesting that creating a category to name them as such produces a forced separation. Therefore, the use of the term seems to exacerbate a fragmentation in language that already existed when competences were separated in domains for operationalisation purposes.

Interviewees also agreed that there is a tension between considering generic competences to be integrated and as part of a whole and the need to separate them in order to make them visible. While these seem dichotomous choices, in other similar ongoing discussions in the field of CBME, it has been argued that different approaches can coexist and that it is necessary to determine when and with what objective to apply one or the other. ${ }^{81}$

The generic/specific distinction, made by several authors and present in competence frameworks - such as those developed in the Tuning Project intends to prioritise these transversal competences, considered of great value given the current dynamism of knowledge. However, this professional practice fragmentation might result artificial and carry frequently unacknowledged consequences.

Interviewees agree the generic competences must be visible in the curriculum for practical purposes, and they agree that separation is useful in planning. They acknowledge the risk of this decision and note that attention must be paid to the way in which they are enunciated. Otherwise, concepts may end up being void of meaning, can be viewed as "non-medical," "soft," extra, optional, non-pertinent or supplementary notions. They might not be viewed as part of a more comprehensive/integrated whole. Interviewees consider that nothing relevant should be taken for granted and that whatever is relevant must be made explicit.

${ }^{80}$ Ministerio de Salud, Guía para la elaboración, 5.

${ }^{81}$ Markku T. Nousiainen et al., "Implementing competency-based medical education. What changes in curricular structure and processes are needed?" Med Teach. 39, no. 6 (June 2017): 594-598, doi: 10.1080/0142159X.2017.1315077. 
Literature suggests that "if languages change in the field of knowledge, it is because there are social changes that demand these languages...[C]hanges do not happen out of context...but result from a relationship that translates into prioritised concepts and arguments" $\$ 2$ [our translation]. This means that the tension expressed by most interviewees arises out of ongoing changes in healthcare professionals' education.

It is worth noting that, even if out of the scope of the analysis in this article, the interviews evidenced certain issues accounting for the tension in the field of training, mainly concerning the various actors and interests involved.

The contributions from other disciplines, interprofessional training and integrated work with the health team enrich physicians' training and enable them to develop a more comprehensive view.

Interviewees are immersed in the current discussions on CBME which are most frequently described in the literature, such as the criticisms to reductionism, the usefulness of breaking down complex practice into manageable units or domains, the need to think about outcomes, the usefulness of frameworks as planning organisers and the several conceptions of competences. However, the disciplinary matrix is still so strong that incorporating generic competences is still a very complex process. In this context, any change entails "yielding power" and the actors involved are not always willing to do it. Interests have even more declarative than action power.

Language is limited, for it can never name everything. This structural condition is inevitable. Only agreements and consensus are viable, ensuring that when a term " $x$ " is used it means "x." The terms used also have "power" and can cause more fragmentation - dissonance - or favour inclusion consonance - depending on what they are used for. Assuming language arbitrariness means assuming the responsibility for its effects.

The choice of the word "generic" was made at a certain time. It was the result of the need to prioritise whatever was considered not belonging in the discipline, whatever was not specific of a profession. The term has had a positive impact in the last years, because it has contributed to prioritising the subject and placing it on the HR training international agenda. Nowadays, it generates dissonance, which must be made explicit, since it may become a hindrance for implementation when teaching these aspects of competences. Hence, acknowledging term arbitrariness and the need for term contextualization, the word "transversal" - meaning "from one side to the other," something that "joins two points" - appears to convey the idea of working with others, which is key for healthcare professionals in today's world.

${ }^{82}$ Gimeno Sacristán, "Diez tesis," 17. 


\section{V.3. Limitations}

This work has clear limitations. On the one hand, it may have achieved better representativeness of a field with so much complexity and diverse actors. On the other hand, these results apply to planners who are immersed in a specific context and theoretical framework, i.e. curricular design planners in healthcare professionals' education. Therefore, results cannot be extrapolated to other contexts.

In addition, this research has not focused on studying all factors connected to the educational reform involved. The study could have been enriched by exploring other aspects that help to reflect on process contextualization and development, as well as on facilitators and resistance. Because all interviewees were involved in medical education, even though they come from different professions, resistance to transversality may have a disciplinary bias.

\section{V.4. Future perspectives: Consequences and workable applications}

This work focuses on a concrete and current aspect in CBME discussions which blazes a trail for future research and revision in practices especially linked to curricular planning and design.

As regards curricular planning and the enunciation of competences, this study is highly relevant as it sets out certain conceptions influencing decisionmaking and change implementation.

In particular, regarding the way competences are enunciated it provides information for understanding the advantages and risks of separating enunciation and it warns about the need to present competences as linked to specific contexts and settled to avoid being seen as disintegrated or ad hoc.

It also highlights the need for a consensus regarding a shared language in the education of health care professionals, and sets forth a concrete proposal on the usage of the term transversal. Synthetic proposals such as EPAs, currently used in CBME, are likely to include GCs explicitly lest they fade away. It will be necessary to consider that, at different training levels, their treatment and inclusion might have different implications.

As for research, this work demands the approach to several aspects inherent to education in the field of healthcare - stakeholders, forces, tensions, resistances. It is likewise essential to dwell deeper into the relationship between language and practices as well as discourse outcomes.

Before considering the use of other terms it would be of the essence to conduct this exploration in groups from different professions, in order to 
clear out whether or not a disciplinary bias is at stake and find out whether this tension is also present in other disciplines with a different theoretical CBE framework.

Being able to think of new names and designs is at this point a necessary step towards consensus efforts. Perhaps not long from now we will be able to simply speak of competence, with the term "competence" as a whole, including transversal components or domains.

\section{Conclusions}

The planners' conceptions explored in this study have revealed the existence of lack of consistency and a shared language as regards generic competences, as well as lack of agreement with respect to terms and their meanings. These locally generated data have shown that medical educators in Argentina do not have a precise common definition of generic competences.

The difficulties around the term "competence" and its use in practice increase when reference is made to generic competences. Here, there is also the contradiction between both words and the tension between the terms "competence" and "generic," which refer to opposed meanings.

Interviewees acknowledge the relevance of generic competences for quality training and care. Most of them agree that at this moment of educational transformation it would be useful to enunciate them separately from the specialty-specific competences. They also state that this fragmented enunciation entails potential risks for curricular planning and assessment, and add that when enunciating them attention has to be paid so that they do not appear as supplementary, empty and ad hoc concepts.

It has to be understood that term choices are arbitrary and have to be interpreted in their context of occurrence. At a certain point in time it was highly relevant to mention generic competences, in order to prioritise them and make them visible. However, the undoubted relevance of generic competences and the importance of enunciation clarity - so that "all of us speak of the same thing" even in different application contexts - demands consensus building regarding their definition and visibility in the curricula, and a decision on the most convenient way of naming them.

\section{Bibliography}

Altermatt, Christel H., ed. Educación Superior en América Latina: reflexiones y perspectivas en Medicina. Bilbao: Universidad de Deusto, 2013. 
. "El proyecto Tuning latinoamericano: la experiencia del área de Medicina." Rev Hosp Clin Univ Chile 25 (2013): 19-31.

Alves de Lima, Alberto E. and Juan P. Costabel. "Marcos de Referencia para la evaluación del desempeño profesional en el ámbito de trabajo.” Rev Fed Arg Cardiol 44, no. 2 (2015): 118-123.

Arce, Hugo E. "Organización y financiamiento del sistema de salud en la Argentina." Medicina 72, no. 5 (2012): 414-418. http://www.scielo.org.ar/pdf/medba/v72n5/ v72n5a11.pdf.

Association of American Medical Colleges. "Physicians for the Twenty-First Century. The GPEP Report: Report of the Panel on the General Professional Education of the Physician and College Preparation for Medicine." J Med Educ. 59, no. 11 (1984): 1-208.

Atkins, Jo. "Tribalism, Loss and Grief: Issues for Multiprofessional Education." Journal of Interprofessional Care 12, no. 3 (1998): 303-307. doi: 10.3109/ 13561829809014121.

Barrera Morales, Marcos F. Modelos epistémicos en Educación y en Investigación. Caracas: Sypal, 2007.

Beneitone, Pablo, César Esquetini, Julia González, Maida Marty Maletá, Gabriela Siufi, and Robert Wagennar, eds. Reflections on and Outlook for Higher Education in Latin America. Final Report Tuning Latin American Project 20042007. Bilbao: Universidad de Deusto, 2007.

Beneitone, Pablo and Edurne Bartolomé. "Global generic competences with local ownership: a comparative study from the perspective of graduates in four world regions." Tuning Journal For Higher Education 1, no. 2 (2014): 303-34. doi:10.18543/tjhe-1(2)-2014pp303-334.

Bleakley, Alan, John Bligh, and Julie Browne. Medical Education for the Future. Identity, Power and Location. Netherlands: Springer Netherlands, 2011. doi: 10.1007/978-90-481-9692-0.

Brailovsky, Carlos A. "Educación médica, evaluación de las competencias." In Aportes para un cambio curricular en Argentina 2001, edited by PAHO/WHO, 103-20. Buenos Aires: Facultad de Medicina, 2001.

Brailovsky Carlos A. and Ángel M. Centeno. "Algunas Tendencias Actuales en Educación Médica.” REDU. Revista de Docencia Universitaria 10 (2012): 23 33. doi: 10.4995/redu.2012.6091.

Carraccio, Carol, Robert Englander, Joseph Gilhooly, Richard Mink, Dena Hofkosh, Michael A. Barone and Eric S. Holmboe. "Building a Framework of Entrustable Professional Activities, Supported by Competencies and Milestones, to Bridge the Educational Continuum.” Acad Med. 92, no. 3 (March 2017): 324-330. doi: 10.1097/ACM.0000000000001141.

Cinque, Maria. “'Lost in translation'. Soft skills development in European countries.” Tuning Journal for Higher Education 3, no. 2 (2016): 389-427. doi: 10.18543/ tjhe-3(2)-2016pp389-427.

Davini, Cristina and María Isabel Duré, coords. Guía para la elaboración de. Documentos Marco de Referencia. Buenos Aires: Mimeo, 2013. 
Duré, María Isabel and María del Carmen Cadile, comps. La gestión de recursos humanos en salud - Una estrategia de consensos 2008-2015. Argentina: Ministerio de Salud de la Nación Argentina, 2015.

Englander, Robert, Jason R. Frank, Carol Carraccio, Jonathan Sherbino, Shelley Ross, Linda Snell, and on behalf of the ICBME Collaborators. "Toward a shared language for competency-based medical education." Medical Teacher 39, no. 6 (2017): 582-587. doi: 10.1080/0142159X.2017.1315066.

Fernandez, Nicolas, Valerie Dory, Louis-Georges, Ste-Marie Monique, Chaput Bernard, and Charlin Andree Boucher. "Varying conceptions of competence: an analysis of how health sciences educators define competence." Medical Education 46 (2012): 357-365. doi: 10.1111/j.1365-2923.2011.04183.x.

Festinger, Leon. A theory of cognitive dissonance. Standford, California: Stanford University Press, 1957.

Foucault, Michel. "La prosa del mundo." In Las palabras y las cosas. Una Arqueología de las ciencias humanas, 26-52. París: Éditions Gallimard, 1966.

Frenk, Julio, Lincoln Chen, Zulfi qar A. Bhutta, Jordan Cohen, Nigel Crisp, Timothy Evans, Harvey Fineberg, et al. "Health professionals for a new century: transforming education to strengthen health systems in an interdependent world." The Lancet 376, no. 9756 (2010): 1923-1958. doi: 10.1016/S01406736(10)61854-5.

Gimeno Sacristán, José. “Diez tesis sobre la aparente utilidad de las competencias en educación.” In Educar por competencias, ¿qué hay de nuevo?, compiled by José Gimeno Sacristán, 15-58. Madrid: Morata, 2008.

Hodges, Brian D. and Lorelei Lingard L. The Question of Competence: Reconsidering Medical Education in the Twenty-First Century. New York: Cornell University Press, 2012.

Holmboe, Eric S., Jonathan Sherbino, Robert Englander, Linda Snell, Jason R. Frank, and on half of the ICBME Collaborators. "A call to action: The controversy of and rationale for competency-based medical education." Medical Teacher 39, no. 6 (2017): 574-581. doi: 10.1080/0142159X.2017.1315067.

Huddle, Thomas S. and Gustavo R. Heudebert. "Viewpoint: Taking Apart the Art: The Risk of Anatomizing Clinical Competence." Acad Med 82 (2007): 536-541.

Irby, David M., Molly Cooke, and Bridget C. O'Brien. "Calls for reform of medical education by the Carnegie Foundation for the Advancement of Teaching: 1910 and 2010." Acad Med. 85, no. 2 (February 2010): 220-7. doi: 10.1097/ACM.0b013e3181c88449.

Jacobs, Johanna, Arno Muijtjens, Scheltus Van Luijk, Cees Van Der Vleuten, Gerda Croiset, and Fedde Scheele. "Impact of institute and person variables on teachers' conceptions of learning and teaching." Medical Teacher 37, no. 8 (2015): 1-9. doi 10.3109/0142159X.2014.970985.

Lattuca Lisa R. and Joan S. Stark. Shaping the college curriculum: Academic plans in context. United States: Jossey-Bass Inc., 2009.

Lazarus, Nabahodoi. "Developing Generic Competences in Life Sciences: the untold story of the Makerere University College of Health Sciences in Uganda.” Tuning 
Journal For Higher Education 4, no. 2 (2017): 389-406. doi: 10.18543/tjhe4(2)-2017pp389-406.

Lee, Nadine van der, Joanne P. I. Fokkema, and Fedde Scheele. "Generic competencies in postgraduate medical training: their importance illustrated by a doctor's narrative on competency-based practice." Zdrav Var 51 (2012): 280-284. doi: 10.2478/v10152-012-0031-y.

Lingard, Lorelei. "What we see and don't see when we look at 'competence': notes on a god term." Adv Health Sci Educ Theory Pract. 14, no. 5 (November 2009): 625-8. doi: 10.1007/s10459-009-9206-y.

Loon, Karsten A. van et al. "The role of Generic Competences in the entrustment of professional activities: A nationwide competency-based curriculum assessed." J Grad. Med. Educ. 8, no. 4 (October 2016): 546-552. doi: 10.4300/ JGME-D-15-00321.1.

Ministerio de Salud de la Nación. Resolution 1342/2007 - Residencias del equipo de salud/Sistema nacional de acreditación de residencias. Official Gazette 26-oct2007 no. 31268.

- Guía para la elaboración de Marcos de Referencia. Argentina: Ministerio de Salud de la Nación, 2013.

Mulder, Martin. "Conceptions of Professional Competence." In International Handbook of Research in Professional and Practice-based Learning, edited by Stephen Billett, Christian Harteis, and Hans Gruber, 107-137. Dordrecht: Springer, 2014.

Nousiainen, Markku T., Kelly J. Caverzagie, Peter C. Ferguson, Jason R. Frank, and on half of the ICBME Collaborators. "Implementing competency-based medical education. What changes in curricular structure and processes are needed?" Med Teach. 39, no. 6 (June 2017): 568-573. doi: 10.1080/0142159X. 2017.1315077.

Palés-Argullós, Jordi and Maria Nolla-Domenjó. "Generic competencies, an unresolved issue in faculties of medicine.” FEM 19, no. 5 (2016): 227-228.

Pan American Health Organization. Health Agenda for the Americas 2008-2017. Washington, D.C.: PAHO, 2007.

- Formación en Medicina orientada hacia la atención primaria de la saludSerie la Renovación de la Atención Primaria de Salud en las Américas. No. 2. Washington D.C.: PAHO, 2008.

Pangaro, Louis and Olle Ten Cate. "Frameworks for learner assessment in medicine: AMEE Guide No78." Med Teach 35, no. 6 (June 2013): 1197-210. doi: 10.3109/0142159X.2013.788789.

Royal College of Physicians and Surgeons of Canada. "Better standards, better physicians, better care." Accessed April 2018. http://www.royalcollege.ca/ rcsite/canmeds/canmeds-framework-e.

Sanne Peters, Geraldine Clarebout, Marc van Nuland, Bert Aertgeerts, and Ann Roex. "A Qualitative Exploration of Multiple Perspectives on Transfer of Learning Between Classroom and Clinical Workplace.” Teach Learn Med. 30, no. 1 (July 2017): 22-32. doi: 10.1080/10401334.2017.1339605. 42. 
Talbot, Martin. "Monkey see, monkey do: a critique of the competency model in graduate medical education." Med Educ. 38, no. 6 (June 2004): 587-92. doi: 10.1046/j.1365-2923.2004.01794.x.

Ten Cate, Olle. "Entrustability of professional activities and competency-based training." Med Educ. 39, no. 12 (2005): 1176-1177. doi: 10.1111/j.1365-2929.2005.02341.x.

_ . "Competency-Based Education, Entrustable Professional Activities, and the Power of Language." J Grad Med Educ. 5, no. 1 (March 2013): 6-7.

- "What is a 21 st century doctor? Rethinking the significance of medical degree."AcadMed.89,no.7(2014):966-9.doi:10.1097/ACM.0000000000000280.

Torres Santomé, Jurjo. Globalización e interdisciplinariedad: el curriculum integrado. España: Ediciones Morata, 1994.

Wagenaar,Robert. "Competences and learning outcomes: a panacea for understanding the (new) role of Higher Education?" Tuning Journal for Higher Education 1, no. 2 (2014): 273-302. doi: 10.18543/tjhe-1(2)-2014pp279-302.

Whitehead, Cynthia R. "Getting off the carousel: De-centring the curriculum in medical education." Perspect Med Educ. 6, no. 5 (October 2017): 283-285. doi: 10.1007/s40037-017-0373-x.

Whitehead, Cynthia R., Brian D. Hodges, and Zubin Austin. "Captive on a carousel: discourses of 'new' in medical education." Adv Health Sci Educ Theory Pract. 18, no. 4 (October 2013):755-68. doi: 10.1007/s10459-012-9414-8.

\section{About the authors}

ROBERTA INÉS LADENHEIM (rladenheim@iuc.edu.ar) is a physician, specialising in Internal Medicine \& Master in Education for Healthcare Professionals. She is the Director of the Medicine Program and Coordinator of the Specialisation Program in Internal Medicine at the Instituto Universitario CEMIC, Buenos Aires, Argentina. She is also active as a teacher in postgraduate training in medical education. Her research interest is linked to the development of competences in healthcare professionals.

CECILIA INÉS HERNÁNDEZ (cineshernandez@gmail.com) is a Psychologist \& Master in Education for Healthcare Professionals. She is Teaching Coordinator at the Provincial Coordination of Teaching \& Research at the Health \& Environment Ministry of the Province of Santa Cruz, Argentina. She is also a teacher at the Virtual Campus of Public Health - PAHO - Argentine Node. Her research interest is linked to healthcare professionals' training. 


\title{
Medical Educators' conceptions about Generic Competences in Argentina: Contributions for consensus building
}

\author{
Roberta Inés Ladenheim and Cecilia Inés Hernández
}

doi: http://dx.doi.org/10.18543/tjhe-5(2)-2018pp99-132

Received: 26.04 .2018

Accepted: 18.05.2018

\section{Copyright}

Copyright for this article is retained by the Publisher. It is an Open Access material that is free for full online access, download, storage, distribution, and or reuse in any medium only for noncommercial purposes and in compliance with any applicable copyright legislation, without prior permission from the Publisher or the author(s). In any case, proper acknowledgement of the original publication source must be made and any changes to the original work must be indicated clearly and in a manner that does not suggest the author's and or Publisher's endorsement whatsoever. Any other use of its content in any medium or format, now known or developed in the future, requires prior written permission of the copyright holder. 